\title{
Penelitian Situs Muara Kaman Dan Upaya Pengembangannya
}

\section{Gunadi Kasnowihardjo}

Keywords: protohistory, borneo, planning, description, spatial

\section{How to Cite:}

Kasnowihardjo, G. (2006). Penelitian Situs Muara Kaman Dan Upaya Pengembangannya. Berkala Arkeologi, 26(1), 45-66. https://doi.org/10.30883/jba.v26i1.924

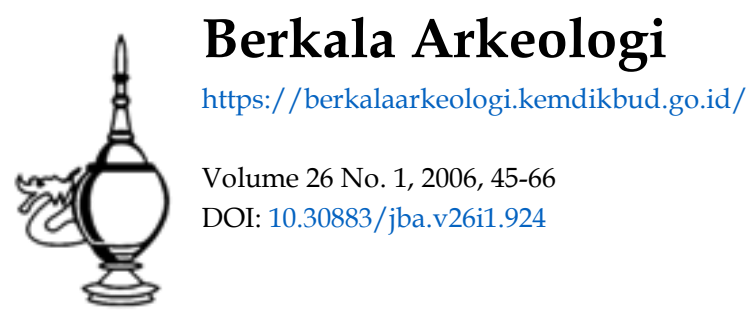

\section{(c) (i)(2)}

This work is licensed under a Creative Commons Attribution-NonCommercial-ShareAlike 4.0 International License. 


\section{PENELITIAN SITUS MUARA KAMAN DAN UPAYA PENGEMBANGANNYA \\ H. Gunadi}

\section{PENDAHULUAN}

\section{A. Latar Belakang}

Situs Muara Kaman yang dikenal dengan temuan beberapa prasasti "yupa" dan diperkirakan berasal dari masa yang sangat awal untuk periode sejarah bangsa Indonesia. Berdasarkan corak dan gaya huruf yang digunakan untuk penulisan prasasti yang dikeluarkan oleh Raja Mulawarman tersebut menunjukkan gaya huruf Pallawa yang digunakan di India pada masa abad IV - V AD (Poerbatjaraka, 1975). Areal ataupun luas kawasan situs cagar budaya Muara Kaman hingga saat ini belum dapat ditentukan. Beberapa kegiatan penelitian histories-arkeologis baik yang dilakukan oleh lembaga penelitian dari pusat (Pusat Penelitian Arkeologi Nasional) maupun Badan Penelitian dan Pengembangan Daerah Kabupaten Kutai Kartanegara bekerja sama dengan Universitas Negeri Malang, belum dapat memberikan penjelasan seberapa luas kawasan atau situs cagar budaya Muara Kaman.

Munculnya Kerajaan Kutai Kuno yang didirikan oleh Raja Mulawarman tidaklah secara tiba-tiba, akan tetapi memerlukan proses yang panjang. Salah satu prasasti yang menyebutkan tentang silsilah yang diawali dari nenek Kundungga yang menurunkan Aswawarman (ayah dari Mulawarman) dapat dipahami bahwa sejak masa Kundungga ini kawasan Muara Kaman diperkirakan sudah berfungsi sebagai kawasan yang penting dalam system perekonomian. Kebesaran Kerajaan Kutai Kuno yang puncaknya dibawah Raja Mulawarman sudah diawali sejak beberapa generasi sebelumnya. Sumberdaya alam seperti emas, gaharu, dan barang komoditi lain yang dimiliki oleh masyarakat pedalaman Kalimantan Timur, kemungkinan sudah dijadikan barang perdagangan sejak masa Kundungga. Posisi Muara Kaman yang sangat strategis karena terletak antara daerah luar dan pedalaman, memungkinkan 
untuk dijadikan tempat pertemuan antara pedagang yang berasal dari luar Kalimantan dan masyarakat pedalaman yang membawa hasil-hasil alam Kalimantan. Posisi strategis di atas juga didukung oleh kondisi geografis bahwa kawasan Muara Kaman terletak pada percabangan sungai (tributary) antara Sungai Mahakam dan Sungai Kedang Rantau, dari kedua daerah hulu sungai-sungai itulah barang-barang sumberdaya alam diangkut ke Muara Kaman.

Nama Sungai Kedang Rantau dapat memberi petunjuk apabila di sekitar pertemuan antara sungai tersebut dengan sungaii Mahakam sejak dahulu telah dijadikan tempat persinggahan bagi orang-orang yang berasal dari daerah hulu maupun hilir. Kata rantau menurut Gazali Usman (2005) berarti tempat persinggahan dalam perjalanan di sungai, sehingga nama Kota Rantau ibukota Kabupaten Tapin di Kalimantan Selatan dahulu merupakan salah satu tempat persinggahan di Sungai Tapin. Dengan kata lain pengertian kata rantau penulis dapat mempersamakan dengan istilah etape dalam kegiatan rally, pada suatu etape baru dapat berhenti. Oleh karena itu tidak mengherankan apabila kawasan Muara Kaman akhirnya dapat berkembang menjadi pelabuhan yang besar dan ramai karena menjadi intra port yang menghubungkan antara pedalaman dan dunia luar. Sejalan dengan perkembangan kawasan tersebut, maka sejak Kundungga orang yang sangat ber')engaruh di kawasan tersebut dia telah menjadi big man dan sekaligus syahbandar yang menguasai barang-barang komodoti baik yang berasal dari pedalaman maupun yang dibawa para pedagang yang berasal dari luar Kalimantan.

Berdasarkan data seperti telah diuraikan di atas, maka dapat disimpulkan bahwa kawasan Muara Kaman sejak masa protosejarah telah menjadi kawasan yang cukup ramai karena menjadi daerah persinggahan dan sekaligus pertemuan antara orang-orang dari pedalaman dan para pedagang yang berasal dari luar Kalimantan. Bagaimana kondisi kawasan Muara Kaman pada waktu itu belum dapat dijelaskan dengan data yang lengkap terutama seberapa luas kawasan purbakala dan dimana pusat-pusat kegiatan yang dilakukan oleh masyarakat di Kerajaan Kutai Kuno pada waktu itu. Pertanyaan-pertanyaan penelitian (research questions) seperti di atas yang akan dicari jawabannya dalam kegiatan survey dan pemetaan kali ini. 


\section{B. Maksud dan Tujuan}

Ada sebuah slogan yang menyebutkan bahwa "kekayaan tinggalan masa lalu adalah salah satu wujud jati diri dari suatu bangsa, dan hanya bangsa yang besar yang dapat menghargai tinggalan dari nenek moyangnya". Kawasan Muara Kaman apabila benar merupakan lokasi Kerajaan Kutai Kuno dari abad IV - V AD, maka dapat dikatakan bahwa awal mula sejarah bangsa Indonesia adalah dari kawasan ini. Sebagai tonggak Sejarah Nasional Indonesia Kerajaan Kutai Kuno mestinya dapat memberikan informasi lebih lengkap dari apa yang telah ditulis dalam Buku Sejarah Nasional Jilid 2. Untuk itulah kegiatan ini dilakukan agar dapat memberikan tambahan informasi tentang sejarah Kutai Kuno. Selain dari itu agar kawasan tersebut dapat didokumentasikan secara lengkap, sebagai salah satu upaya penyelamatan dan pelestarian kawasan cagar budaya yang merupakan asset bangsa yang tidak ternilai harganya.

Adapun tujuan kegiatan ini selain untuk mengetahui secara visual potensi cagar - budaya Muara Kaman, Kabupaten Kutai Kartanegara dari hasil pemetaan tersebut akan dapat dijadikan sebagai acuan bagi Pemerintah Kabupaten Kutai Kartanegara dalam menentukan areal cagar budaya yang perlu diselamatkan. Pembangunan yang tidak mempertimbangkan pelestarian dan penyelamatan situs arkeologi yang sedang berlangsung di kawasan Muara Kaman juga akan berdampak kaburnya informasi tentang masa lampau. Dengan melaksanakan kegiatan ini, maka dapat dikatakan bahwa Penyelamatan Kawasan Cagar Budaya Muara Kaman ini merupakan upaya Preserved by Record suatu kawasan cagar budaya yang menghadapi ancaman kepunahan. Ancaman tersebut dapat secara langsung maupun tidak langsung, seperti sering terjadinya penggalian liar yang dilakukan oleh masyarakat setempat yang bertujuan mencari barang antiq, jelas merupakan ancaman langsung bagi kelestarian benda cagar budaya. Sedangkan adanya pembangunan infra struktur seperti pembuatan jalan dengan memotong sebuah bukit, kadang-kadang bulldozer yang digunakan menemukan benda-benda yang diperkirakan benda cagar budaya, tetapi sudah dalam kondisi hancur.

\section{Metode}

Kegiatan Penyelamatan Situs Cagar Budaya Muara Kaman ini dibagi dalam 
beberapa sub kegiatan yang meliputi : pemetaan, inventarisasi dan dokumentasi potensi tinggalan kuno, plotting dan zoning atau sonasi wilayah. Sub kegiatan pemetaan dilakukan secara konvensional dengan menggunakan alat pesawat ukur BTM tipe T nol. Walaupun pemetaannya dilakukan secara manual, akan tetapi hasil dari pengukuran tersebut diolah dalam program computer dengan menggunakan program autocad, sehingga dapat dikonversikan dalam bentuk digitalisasi. Selanjutnya, kegiatan pemetaan ini akan diikuti oleh kegiatan total survey yang akan mehiput seluruh areal kegiatan dengan melakukan inventarisasi tinggalan baik yang bergerak maupun tidak bergerak yang diikuti dengan tindakan pendokumentasian. Kegiatan yang lain adalah plotting posisi potensi kepurbakalaan dengan menggunakan alat yang dikenal dengan nama Geographic Position System (GPS) untuk menentukan koordinat suatu temuan atau potensi kepurbakalaan. Selanjutnya kegiatan yang terakhir adalah zoning kawasan untuk menentukan prioritas dalam pengembangan kawasan tersebut berdasarkan potensi benda cagar budaya yang ditemukannya.

Kegiatan penyelamatan dengan melakukan pemetaan di wilayah Muara Kaman ini juga akan di back up dengan aplikasi program map source dan dilengkapi dengan posisi koordinat potensi sumberdaya arkeologis yang ditemukan di dalam kawasan tersebut.

\section{KEGIATAN PENELITIAN}

Sebagai tonggak sejarah nasional Indonesia, Kutai belum banyak diketahui dan diminati oleh para ahli arkeologi maupun sejarah. Kalaupun Pusat Penelitian Arkeologi Nasional dan Balai Arkeologi Banjarmasin tahun 1997 dan 1998 telah melakukan kegiatan penelitian di kawasan Muara Kaman, akan tetapi sangat disayangkan hasil penelitian pada saat itu belum mendapatkan data yang siknifikan (Machi Suhadi Dkk. 1997; Bambang Sulistyanto Dkk.1998, baca pula: Vida Pervaya Dkk. 1998). Mengapa Kerajaan masa Hindu-Budha tertua di Indonesia ditemukan di kawasan Muara Kaman, Kabupaten Kutai Kartanegara, Propinsi Kalimantan Timur?

Pertanyaan penelitian di atas rupa-rupanya hingga tahun 1990 qn belum ditanggapi secara serius oleh para ahli sejarah maupun ahli arkeologi kita. Nyatanya, 
dalam buku Sejarah Nasional Indonesia jilid II yang telah mengalami beberapa kali revisi dalam uraian tentang kerajaan-kerajaan kuno di Indonesia, Kerajaan Kutai dibawah Raja Mulawarman yang berkembang pada abad IV - V Masehi hanya ditulis beberapa kalimat saja. Padahal apabila kita perhatikan Kutai memiliki tinggalan dari masa prasejarah, protosejarah, dan sejarah yang sangat potensial untuk diungkapkan dalam melukiskan tentang sejarah peradaban bangsa Indonesia pada masa prasejarah, protosejarah hingga masa sejarah. Selama tiga tahun terakhir (2004, 2005 dan 2006) Balai Penelitian Arkeologi Wilayah Kalimantan, Universitas Negeri Malang, dan Badan Penelitian dan Pengembangan Daerah Kabupaten Kutai Kartanegara telah melakukan kegiatan penelitian secara kolaboratif antara arkeologi dan sejarah di kawasan Muara Kaman. Penelitian tahap I (2004) merupakan penelitian yang bersifat eksploratif dengan melakukan survey kawasan yang cukup luas, bahkan mencapai daerah-daerah di luar Muara Kaman seperti Kota Bangun dan Anggana yang mempunyai keterkaitan dengan Kerajaan Kutai Kartanegara. Secara geografis, kawasan Muara Kaman yang terdiri dari daerah aliran sungai (das), rawa-rawa, dan tanjung yang berbukit, maka penelitian untuk tahap I ini penggalian (excavation) dikonsentrasikan di sekitar tanjung, karena diperkirakan di tanjung-tanjung inilah banyak dilakukan kegiatan pada masa lampau, seperti di Tanjung Gelombang dan Tanjung Serai.

Penggalian di Tanjung Gelombang tidak diharapkan adanya temuan yang siknifikan seperti struktur bangunan, karena lokasi yang sebagian besar menupakan tanah yang relative datar ini oleh tim peneliti sementara diperkirakan sebagai tanah lapang yang disebut dengan Waprakeswara seperti tersurat dalam salah satu prasasti Mulawarman. Oleh karena itu penggalian difokuskan pada lokasi-lokasi di luar areal tersebut. Hasil penelitian yang cukup siknifikan ditemukan di sektor Tanjung Serai, seperti sisa-sisa struktur bata (?), lapisan tanah pengerasan, serta sejumlah manik-manik dari berbagai jenis. Penelitian di sektor Tanjung Serai ini didasari oleh temuan peripih batu oleh penduduk setempat bernama Wen yang telah melakukan "penggalian liar" beberapa tahun yang lalu. Kita tahu bahwa peripih adalah tempat menyimpan relic yang merupakan inti dari suatu bangunan suci seperti candi, dan peripih tersebut biasanya ditanam dibawah bangunan. Dengan adanya temuan peripih tersebut dapat dipastikan bahwa bangunan dan sisa-sisa pendirian

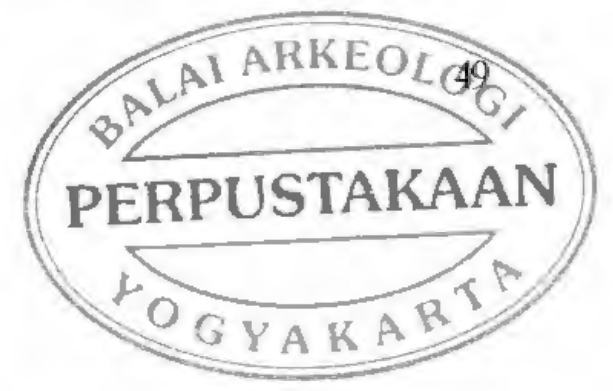


pondasinyapun telah terangkat atau terbongkar. Tetapi perlu diingat bahwa bangunan candi pada abad IV - V Masehi tidak sama dengan candi-candi yang ditemukan di Jawa dan Sumatera yang berasal dari masa yang jauh lebih kemudian. Candi yang dibangun oleh Mulawarman diperkirakan berupa bangunan berteras dan terbuat dari bata yang mirip dengan sebuah altar. Hal ini dapat diketahui bahwa di lokasi penelitian tidak banyak ditemukan sisa-sisa bata. Kesimpulan sementara di atas diperkuat oleh beberapa penduduk setempat yang sering melakukan kegiatan "penggalian liar" menyatakan tidak pernah menemukan sisa-sisa bata dalam jumlah yang banyak.

Penelitian tahap II (2005) merupakan lanjutan dengan sasaran melokalisasi dan menentukan areal yang disebut Waprakeswara dan lokasi dimana kira-kira tugu Yupa didirikan. Tugu Yupa yang disebut-sebut sebagai tanda terima kasih para Brahmana kepada Raja Mulawarman ini didirikan untuk memperingati peristiwa yang sangat penting yaitu upacara Bahusuwarnakam dan upacara korban dan sedekah lainnya yang diselenggarakan oleh Raja Mulawarman. Seperti disebutkan dalam prasasti bahwa Raja Mulawarman telah melakukan upacara korban dengan menyembelih puluhan ribu lembu, serta memberikan sedekah dengan membagi-bagi minyak kental dan lampu, serta emas baik kepada rakyat maupun kepada para Brahmana yang datang dari berbagai daerah.

Hasil penelitian tahap II yang cukup penting adalah bahwa tim peneliti dapat membedakan pengertian tugu Yupa dan prasasti Yupa. Para peneliti terdahulu selalu menyebut prasasti-prasasti Raja Mulawarman ini dengan istilah yupa. Menurut hemat kami ini merupakan kesalah kaprahan, sehingga tinggalan sebuah batu berukuran panjang $260 \mathrm{Cm}$ yang tergeletak di Tanjung Gelombang oleh para peneliti terdahulu diinterpretasikan sebagai bakalan prasasti. Tim peneliti kali ini berpendapat lain, batu yang oleh masyarakat setempat disebut Lesung Batu tersebut adalah tugu batu Yupa yang didirikan oleh para Brahmana. Tetapi sangat disayangkan bahwa batu tersebut hingga posisinya yang terakhir sedikitnya telah mengalami tiga kali perpindahan. Bahkan konon kabarnya batu tersebut pemah akan diangkut ke Tenggarong, oleh karena sesuatu hal maka dibatalkan dan diletakkan di tempat yang sekarang. Hipotesa sementara tim peneliti kali ini menyatakan bahwa lokasi 
Pendirian tugu Yupa tersebut disekitar tepian Sungai Kedangrantau dan pada areal yang dikenal sebagai Waprakeswara. Adapun alasan yang pertama, batu yang berukuran cukup besar dan berat tersebut diperkirakan belum terlalu jauh tertransportasi dari posisi awalnya. Alasan yang kedua, bahwa tugu Yupa yang dimasudkan sebagai peringatan tentang keluhuran budi seorang raja tersebut dapat selalu terlihat oleh masyarakat yang berlalu lalang di alur sungai Kedangrantau maupun masyarakat yang berada di sekitar Waprakeswara. Sedangkan keyakinan penulis bahwa area yang disebut-sebut dalam prasasti sebagai waprakeswara adalah areal disekitar lokasi Lesung Batu sekarang, karena selain merupakan areal yang relative datar sehingga dapat dijadikan sebagai pusat kegiatan, di lokasi tersebut juga ditemukan sebuah tugu batu (menhir) yang berukuran lebih kecil yang diperkirakan sebagai tugu untuk mengikat binatang korban saat dilangsungkannya upacara keagamaan di arena waprakeswara tersebut.

Untuk hasil penelitian arkeologi-sejarah Tahap III, temuan yang cukup siknifikan adalah struktur tiang kayu yang diperkirakan bekas bangunan rumah panggung dalam ukuran yang sangat besar. Hal ini berdasarkan temuan tonggak-tonggak kayu dengan garis tengah antara $30-35 \mathrm{Cm}$. Struktur tiang kayu tersebut ditemukan di ujung tanjung yang berbatasan antara daratan dan rawa-rawa. Dengan demikian dapat diprediksi bahwa permukiman pada waktu dahulu terletak pada kawasan rawa-rawa dengan rumah-rumah panggung. Untuk memastikan hipotesis di atas perlu dilakukan analisis pertanggalan absolute dengan mengambil beberapa sample kayu dari berbagai ukuran tiang yang ditemukan untuk dilakukan penentuan pertanggalan dengan menggunakan metode Carbon 14. Mudah-mudahan sekelumit data yang diperoleh dari Muara Kaman ini dapat memberikan sumbangan bagi sejarah bangsa Indonesia, terutama masa-masa awal perjalanan sejarah bangsa Indonesia.

\section{KEGIATAN PENGEMBANGAN}

Secara garis besar kegiatan penyelamatan Situs Cagar Budaya Muara Kaman Kabupaten Kutai Kartanegara, dapat dibedakan menjadi dua kegiatan yaitu pemetaan dan survey. Hasil seluruh rangkaian kegiatan akan dapat dilaporkan seperti diuraikan di bawah. 


\section{A. Pemetaan}

Kegiatan pemetaan yang menggunakan peralatan konvensional alat ukur BTM tipe T nol ini diawali dari Tugu Monumen Perjuangan Rakyat Muara Kaman, yang dijadikan pengikat sebagai titik 0.0 (datum point). Dari titik pengikat atau datum point (DP) dilanjutkan ke arah utara menyusuri sungai Mahakam sepanjang 100 meter. Dari titik ini pemetaan diarahkan ke seberang sungai Mahakam untuk mengetahui lebar sungai tersebut. Setelah melewati kawasan Makam Martapura dan terus mengikuti alur sungai ke arah hulu. Setelah melewati tikungan sungai Mahakam, pemetaan diarahkan ke Kampung Muara Kaman Seberang menyusuri kehilir kembali ke percabangan sungai atau daerah muara Sungai Kedang Rantau. Pemetaan dilanjutkan dengan menyusuri Sungai Kedang Rantau ke arah hulu hingga mencapai kawasan Tanjung Gelombang dan Tanjung Serai. Setelah melintasi Sungai Kedang Rantau dan memetakan areal sekitar Loa Genting hingga seluruh kawasan Tanjung Gelombang dan Tanjung Serai. Dari Tanjung Serai pemetaan dilanjutkan dengan menyusuri lereng kearah barat menuju jalan poros desa hingga mencapai kawasan Kantor Camat Muara Kaman. Dari sini pemetaan diteruskan hingga kawasan Danau Lipan dan menyambung hingga titik 0.00. Dengan demikian maka kegiatan pemetaan ini telah dapat menggambarkan batas terluar areal pemetaan. Areal ini adalah suatu universe dari kawasan Muara Kaman yang diperkirakan sebagai kawasan kegiatan yang berlangsung sejak kira-kira 1.500 tahun yang lalu.

\section{B. Survei}

Secara garis besar kegiatan survey ini mencakup dua hal pokok yaitu pertama inventarisasi dan dokumentasi, dan kedua mencakup plotting dengan menggunakan GPS, sedang kegiatan yang terakhir adalah sonasi kawasan yang berkaitan dengan perencanaan pengembangan kawasan cagar budaya Muara Kaman.

1. Inventarisasi dan Dokumentasi Potensi Cagar Budaya Muara Kaman.

Kawasan Muara Kaman yang telah dikenal sejak abad IV - V AD, rupa-rupanya hingga abad XVIAD kawasan ini masih menjadi perhatian orang hal ini dibuktikan dengan ditemukannya tinggalan benda-benda keramik baik yang berasal dari Cina, Vietnam maupun Thailand. Bahkan pada masa-masa perjuangan kemerdekaan, kawasan ini juga memegang peranan penting dalam menegakkan Negara Kesatuan Republik Indonesia, yang dibuktikan adanya monument perjuangan rakyat Muara 
Kaman yang dipimpin oleh Muso orang asli Muara Kaman. Bukti tinggalan masa Mulawarman yang berupa prasasti-prasasti batu yang sekarang disimpan di $\mathrm{Mu}$ seum Nasional memang belum dapat ditemukan secara pasti lokasi dimana prasasti tersebut didirikan. Begitu pula batu Yupa yang sekarang dikenal oleh masyarakat sebagai Lesung Batu yang tergeletak di kawasan Tanjung Gelombang juga sudah bergeser dari tempatnya semula.

\section{Plotting dan Koordinat Potensi Cagar Budaya}

Dengan melakukan pengukuran koordinat pada setiap lokasi tinggalan Arkeologis yang kemudian di plot pada hasil pemetaan situs cagar budaya Muara Kaman, maka akan diketahui antara lain kepadatan tinggalan pada suatu kawasan. Ploting yang dilakukan berdasarkan hasil pengukuran koordinat dengan GPS ini untuk melengkapi data dalam kegiatan pemetaan. Dengan demikian maka hasil ploting selanjutnya akan mempermudah dalam melakukan sonasi atau pemintakatan kawasan tersebut.

\section{Zoning atau Sonasi/Pemintakatan.}

Sonasi atau pemintakatan suatu kawasan cagar budaya perlu dilakukan terutama apabila suatu kawasan akan dilakukan pengembangan maupun pemanfaatannya. Dengan melakukan sonasi tersebut, maka akan dapat diketahui dimana kawasan yang dapat digunakan sebagai tempat untuk kepentingan umum dan tempat-tempat atau kawasan yang harus dilindungi dan tidak dapat digunakan sebagai arena aktivitas umum. Di kawasan Muara Kaman ini sonasi dapat dibagi dalam tiga tingkatan atau zona yaitu : Zona I meliputi areal tinggalan arkeologis yang harus dilindungi dan tidak dapat digunakan sebagai tempat fasilitas umum. Pemanfaatan untuk zona ini khusus sebagai "atraksi" yang dapat dimanfaatkan sebagai obyek kajian, studi maupun sebagai obyek kunjungan semata bagi para wisatawan yang hanya ingin sekedar tahu. Zona II merupakan areal penyangga sona I dimana di areal tersebut dapat dibangun beberapa bangunan pendukung seperti museum, diorama dan atraksi lain yang berkaitan dengan cagar budaya Muara Kaman. Sedangkan pada Zona III merupakan zona pengembangan dimana di areal tersebut dapat dimanfaatkan sebagai sarana dan fasilitas bagi umum seperti souvenir shops, rest room, lapangan parker dan bangunan fasilitas lainnya. 
Dalam kaitannya dengan sonasi Situs Cagar Budaya Muara Kaman ini, kawasan yang dijadikan sasaran utama atau dimasukkan dalam zona I yaitu kawasan sekitar Lesung Batu dan secara sporadic beberapa lokasi lainnya seperti lembah kaki bukit Tanjungserai tempat ditemukan struktur tonggak kayu yang diperkirakan sebagai tiang-tiang bangunan permukiman masa lampau.dan salah lokasi di Banua Lawas yang dicurigai sebagai lokasi bangunan pemujaan (sejenis candi?) yang tepatnya terletak dibelakang PLN Muara Kaman. Penentuan sonasi untuk kawasan Situs Cagar Budaya Muara Kaman tidak dapat ditentukan secara konsentris seperti yang lazim dilakukan pada kompleks bangunan candi-candi di Jawa yangt tersusun dengan bentuk yang memusat. Akan tetapi sonasi disini dilakukan secara parsial dengan system sel-sel sesuai dengan lingkungan dan kondisi lansekapnya seperti terlihat pada peta terlampir. Selain itu hasil sonasi ini juga dapat digunakan untuk menentukan berapa luas lahan yang akan dibutuhkan dalam kaitannya dengan penyelamatan situs cagar budaya Muara Kaman.

\section{PENUTUP}

\section{A. Kesimpulan}

Berdasarkan data sejarah dan tinggalan arkeologis serta benda cagar budaya lain yang ditemukan di kawasan Muara Kaman, baik berdasarkan hasil penelitian maupun hasil pemetaan di situs cagar budaya Muaraka Kaman, maka dapat disimpulkan bahwa Muara Kaman merupakan sebuah situs sejarah - purbakala yang telah berlangsung sejak abad IV - V AD hingga masa kemerdekaan tahun 1945 an. Dengan demikian maka Muara Kaman dapat dikatakan sebagai situs sejarah - purbakala yang diperkirakan paling tua dan paling panjang di Indonesia. Apabila perkiraan tersebut benar, maka tidak ragu-ragu apabila kawasan Muara Kaman harus diselamatkan dan dilestarikan sebagai salah satu pusaka warisan nenek moyang yang harus dijaga sebagai asset bangsa hingga anak cucu nanti.

Dari hasil pemetaan selain dapat ditentukan luas kawasan Cagar Budaya Muara Kaman, juga akan dapat dilihat bagaimana densitas atau kepadatan temuan tinggalan sejarah dan purbakala di kawasan tersebut. Kompleksitas kawasan Muara Kaman dapat diketahui dari berbagai temuan atau tinggalan dari masa lampau seperti adanya 
situs pemujaan, situs permukiman, maupun situs penguburan (?). Dimana mereka melakukan aktivitas pertanian terutama penanaman padi sebagai makanan pokok mereka? Oleh karena lahan lain yang ada di kawasan Muara Kaman adalah berupa rawa-rawa, maka kemungkinan besar di lahan itulah mereka membudidayakan tanaman padi terutama saat musim kering.

Hasil dari kegiatan pemetaan situs cagar budaya Muara Kaman, dapat ditentukan beberapa zone inti yang harus diprioritaskan untuk dilestarikan dan diselamatkan adalah Zone Adi area Lesung Batu, Zone B di lokasi temuan tiang-tiang kayu di kaki Tanjung Serai, dan Zone C di belakang kantor PLN Muara Kaman. Untuk pengembangan Zone A dibutuhkan lahan $25.000 \mathrm{M}^{2}$, Zone A ini merupakan sona inti dan di sini akan dibangun beberapa fasilitas utama seperti museum dan fasilitas penunjang lainnya. Di zone A ini pemerintah Kabupaten Kutai Kartanegara telah membebaskan lahan seluas $1 \mathrm{Ha}$, sehingga masih ada kekurangan sekitar $1.5 \mathrm{Ha}$. Untuk Zone $\mathrm{B}$ dan $\mathrm{C}$ yang merupakan sona penyangga juga diperlukan pembebasan - lahan yaitu seluas $2.400 \mathrm{M}^{2}$ untuk pengembangan zone B dan $500 \mathrm{M}^{2}$ untuk pengembangan Zone $\mathrm{C}$, jumlah tersebut sudah termasuk untuk keperluan pembuatan jalan setapak selebar 2 meter yang menghubungkan antara Zone inti dan zone-zone penyangga. Apabila dikemudian hari kawasan ini dikembangkan seperti usulan di atas, maka kawasan Situs cagar budaya tersebut akan dapat pula dimanfaatkan sebagai obyek wisata budaya yang sangat berguna bagi pendidikan generasi muda kita khususnya dan masyarakat luas pada umumnya. Dampak lain yang akan dirasakan oleh masyarakat Muara Kaman adalah rasa bangga akan potensi sumberdaya arkeologi yang dimilikinya, yang akan dapat mengangkat jati diri masyarakat setempat.

\section{B. Rekomendasi}

Untuk menunjukkan kepada masyarakat luas terutama kepada penduduk di sekitar Muara Kaman tentang pentingnya situs cagar budaya tersebut, maka areal situs kawasan cagar budaya Muara Kaman perlu diberikan tanda batas situs atau areal kawasan cagar budaya. Pemberian tanda batas situs ini pertama sebagai langkah sosialisasi kepada masyarakat sekitar. Kemudian setelah masyarakat dapat memahami, maka diharapkan tidak ada lagi upaya untuk melakukan penggalian 
liar di kawasan tersebut. Bahkan dapat diharapkan bahwa diwaktu mendatang apabila ada seseorang yang menemukan benda-benda yang dicurigai sebagai benda cagar budaya akan melaporkan kepada yang berwajib.

Sebagai langkah dalam upaya melindungi dan melestarikan situs cagar budaya Muara Kaman, maka langkah berikutnya adalah penerbitan Surat Keputusan tentang Kawasan Cagar Budaya Muara Kaman yang dapat dikeluarkan oleh Bupati Kutai Kartanegara atau Gubernur Propinsi Kalimantan Timur. Langkah selanjutnya adalah penyusunan PERDA tentang Kawasan Cagar Budaya yang disyahkan oleh Dewan Perwakilan Rakyat Kabupaten Kutai Kartanegara ataupun Dewan Perwakilan Rakyat Propinsi Kalimantan Timur. Agar Muara Kaman dapat dikenal oleh masyarakat Indonesia, maka kawasan Muara Kaman perlu dikembangkan sebagai salah satu Taman Purbakala di Kabupaten Kutai Kartanegara.

Sebelum dapat merealisasikan pembangunan Taman Purbakala ataupun $\mathrm{Mu}$ seum Mulawarman di Situs Cagar Budaya Muara Kaman, dapat direkomendasikan bahwa berdasarkan pemetaan tersebut maka langkah yang paling konkrit adalah melakukan pembebasan tanah (walaupun secara parsial dan tidak perlu membebaskan tanah secara blok) pada lokasi-lokasi tinggalan sejarah yang potensial, serta melakukan pemagaran agar dapat diketahui dan dipahami oleh masyarakat luas akan pentingnya pelestarian suatu situs cagar budaya.

Lokasi yang perlu dibebaskan adalah lokasi ditemukan sisa-sisa struktur batu yang diperkirakan merupakan sisa-sisa dari bangunan sacral yang berukuran \pm 10 meter X 10 meter, lokasi ini terletak kira-kira 200 meter sebelah selatan PLN Muara Kaman dan disebut situs Candi A. Lokasi lain yang perlu dibebaskan adalah lokasi ditemukannya struktur tiang-tiang kayu yang membentuk denah empat persegi panjang di lembah Tanjung Serai. Susunan tiang-tiang kayu ini diperkirakan sisasisa tiang utama rumah panggung. Untuk mengetahui umur perkampungan di Tanjung Serai tersebut perlu dilakukan dating dengan mengambil sample sebagian dari tiang kayu untuk dilakukan analisis dengan menggunakan carbon 14 (Carbon dating) di Badan Tenaga Atom Nasional (BATAN). Temuan serupa juga didapatkan di lokasi antara Tanjung Gelombang dan Tanjung Serai, walaupun baru diketahui sebuah 
sisa tiang kayu.

Untuk dapat memanfaatkan temuan-temuan tersebut, maka selain membebaskan lokasi secara parsial, perlu diberikan sarana jalan akses ke tempat-tempat tersebut. Oleh karena itu diusulkan pula untuk membebaskan tanah guna pembuatan jalan setapak dari lokasi Lesung Batu ke Tanjung Serai dan ke lokasi Situs Candi A. Lahan seluas 10.000 meter di sekitar lokasi Lesung Batu yangt telah dibebaskan Pemerintah Kabupaten Kutai Kartanegara, merupakan modal dasar dalam perencanaan pengembangan dan sekaligus pelestarian Situs Cagar Budaya Muara Kaman. Sesuatu yang cukup siknifikan untuk dapat diangkat dan ditampilkan dalam kawasan situs cagar budaya Muara Kaman adalah lokasi tempat didirikan keenam Prasasti dan sebuah Yupa seperti yang tertulis dalam prasasti yang dikeluarkan oleh Raja Mulawarman, yang hingga saat ini belum dapat ditemukan. Oleh karena itu dalam rekomendasi ini kami menyarankan kepada Pemerintah Kabupaten Kutai Kartanegara Cq. Badan Penelitian dan Pengembangan Daerah Kutai Kartanegara untuk dapat melakukan penelitian lebih khusus tentang pengkajian dimana lokasi berdirinya keenam prasasti tersebut. Hal ini untuk dapat merekonstruksi keenam prasasti dan sebuah yupa ke tempat aslinya walaupun hanya menggunakan copy dari benda-benda aslinya yang tidak mungkin kita kembalikan ke tempat aslimya.

\section{DAFTAR PUSTAKA}

Bambang Sulistyanto, 1998. "Laporan Penelitian Arkeologi Pemetaan Situs Muara Kaman Kabupaten Kutai, Kalimantan Timur”, Balai Arkeologi Banjarmasin.

Bellwood, Peter, 2000. Prasejarah Kepulauan Indo-Malaysia, Edisi Revisi dalam Bahasa Indonesia, Penerbit Gramedia, Jakarta.

Dwi Cahyono dan Gunadi, Laporan Penelitian Arkeologi-Sejarah Situs Muara Kaman, Kutai Kartanegara Tahap I Tahun 2004, BALITBANGDA Kabupaten Kutai Kartanegara, Universitas Negeri Malang, dan Balai Arkeologi Banjarmasin (belum diterbitkan). 
Dwi Cahyono dan Gunadi, Laporan Penelitian Arkeologi-Sejarah Situs Muara Kaman, Kutai Kartanegara Tahap II Tahun 2005, BALITBANGDA Kabupaten Kutai Kartanegara, Universitas Negeri Malang, dan Balai Arkeologi Banjarmasin (belum diterbitkan).

Gunadi, 2004. "Sungai Jelai dan Hunian Purba di Kawasan Tepian Langsat, Kutai Timur, Kalimantan Timur”, dalam: Gunadi et.al.: Sungai dan Kehidupan Masyarakat di Kalimantan, diterbitkan oleh Ikatan Ahli Arkeologi Indonesia Komisariat Daerah Kalimantan.

Gunadi, 2006. "Laporan Penelitian Arkeologi di Daerah Aliran Sungai Kayan", Balai Arkeologi Banjarmasin, Belum diterbitkan.

Machi Suhadi, 1997/1998. "Laporan Penelitian Arkeologi di Muara Kaman, Kabupaten Kutai, Kalimantan Timur, 1998”. Pusat Penelitian Arkeologi Nasional, Departemen Pendidikan dan Kebudayaan.

McKinnon, E. Edwards, Buddhism And the Pre-Islamic Archaeology of Kutei In the Mahakam Valley of East Kalimantan, August 1997. (unpublished).

McKinnon, E. Edwards, Pre-Islamic Gold Artefacts in the Kutei Museum, Tenggarong, Kabupaten Kutei, Samarinda : June 1997. (unpublished).

McKinnon, E. Edwards, A Note on Recent Ceramic Finds at Muara Kaman, Kabupaten Kutei, Kalimantan Timur, Catatan Perjalanan yang belum di Publikasikan.

Poerbatjaraka, Prof. Dr, Riwayat Indonesia Jilid I, Jajasan Pembangunan Djakarta, MCMLII, Disalin dan diperbanyak dengan ejaan baru oleb Ikatan Keluarga Arkeologi "Purbayasa" Yogyakarta tahun 1975.

Vida Pervaya Rusianti Kusmartono (Ketua Tim), 1998. "Laporan Hasil Penelitian 


\section{Arkeologi: Ekskavasi di Situs Bukit Brubus, Kabupaten Kutai, Kalimantan Timur", Balai Arkeologi Banjarmasin.}

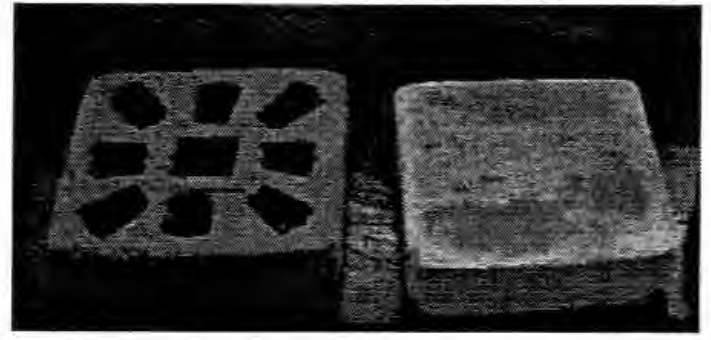

Baru Peripih berukuгал $20 \mathrm{~cm}$ x $20 \mathrm{~cm}$, ditemukan Penduduk tahun 1995

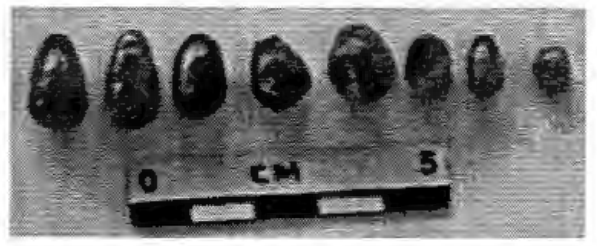

Manik-manik Kamelian, hnsil penggalian Di Tanjungserai

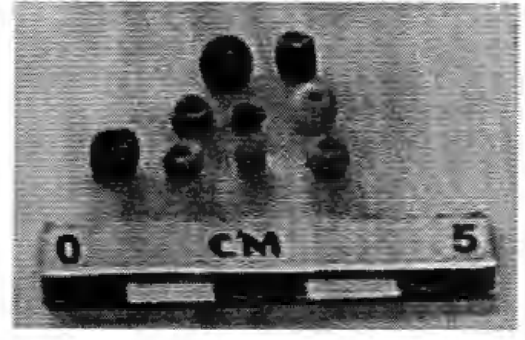

Manik-manik kaca hasil penggalian di Tanjungseraidi Tanjungserai

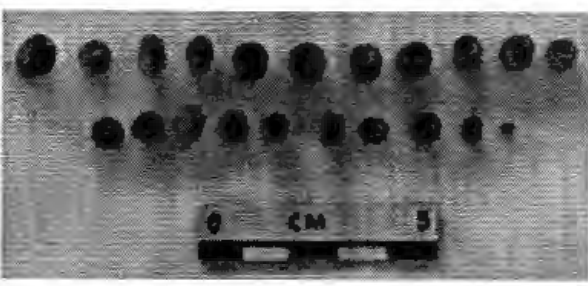

Manik-manik dari tanah bakar, hasil penggalian di Tanjungserai

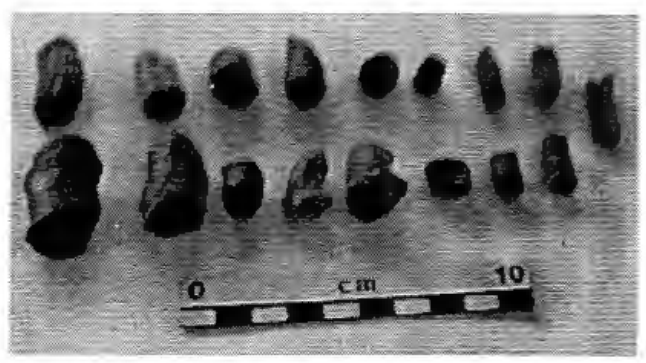

Manik-manik batu local(?), temuan penggalian

di Tanjungserai 


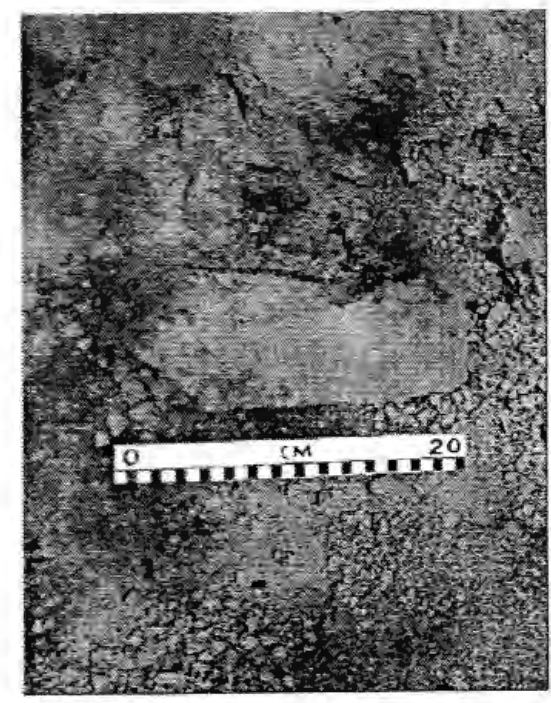

Sisa-sisa struktur bata yang telah Menyatu dengan tanah dan sulit Untuk dibedakan, hasil penggalian Di Tanjungserai

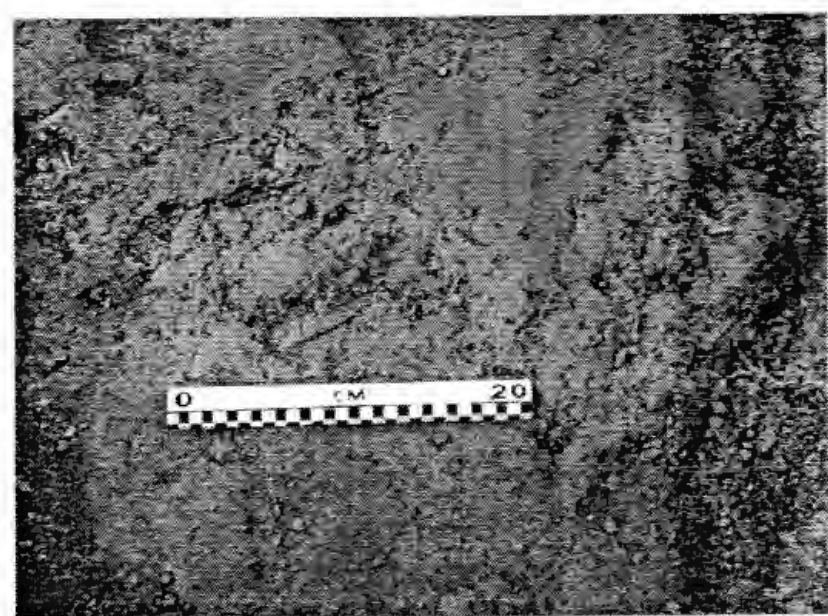

Lapisan tanah yang dikeraskan secara artifisial hasil penggalian di Tanjungserai

\section{Lampiran-Lampiran}

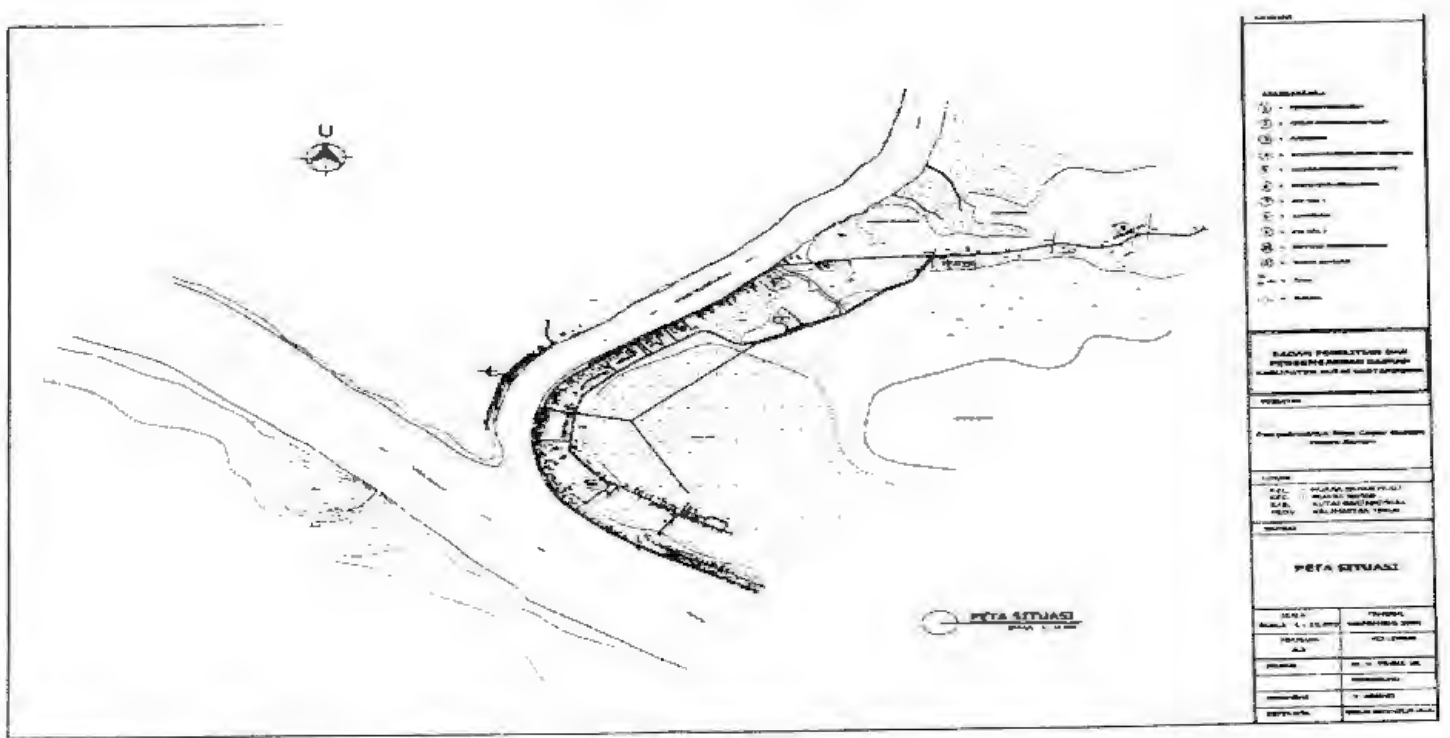

Lampiran Peta Kawasan Cagar Budaya Muara Kaman 


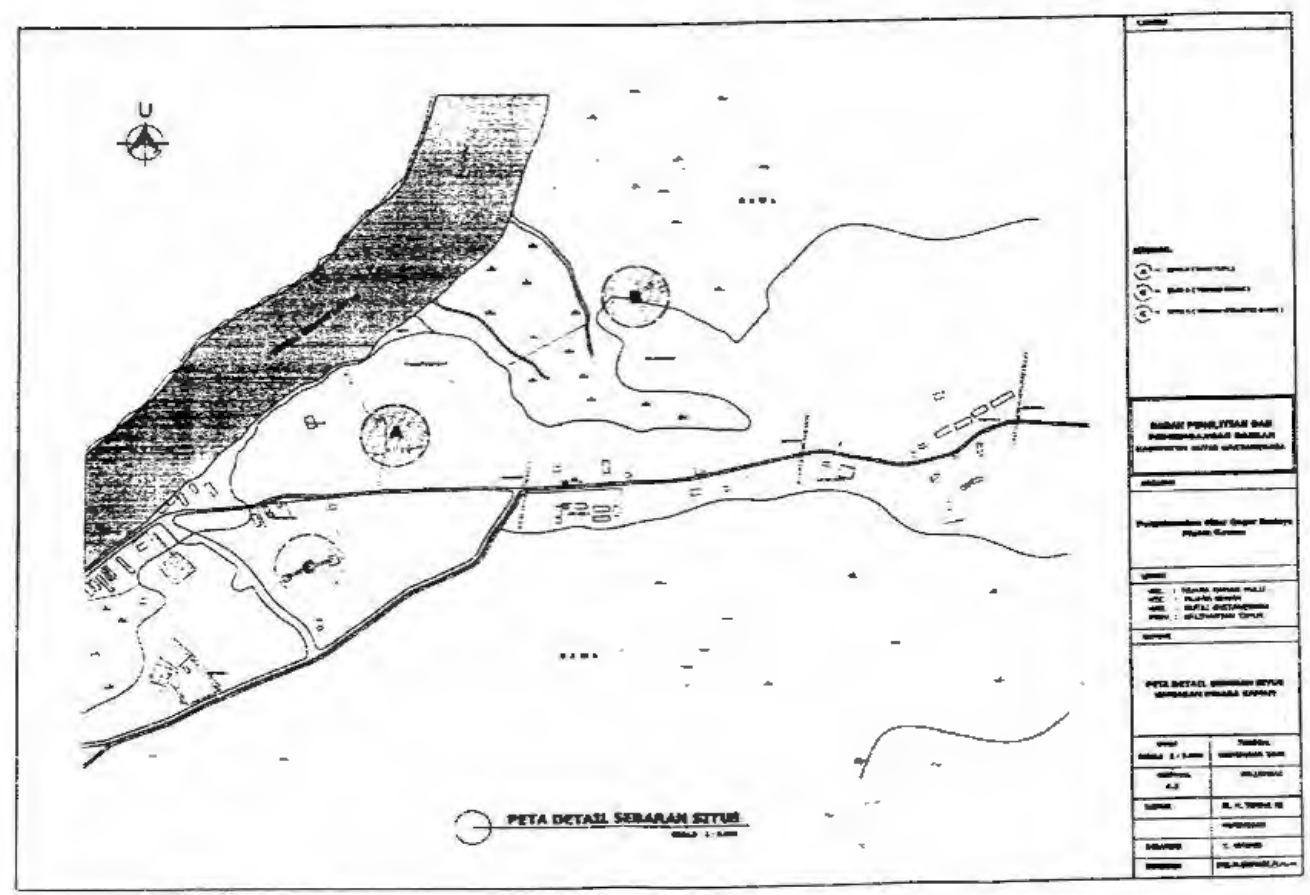

Peta Sonasi Kawasan Situs Cagar Budaya Muara Kaman

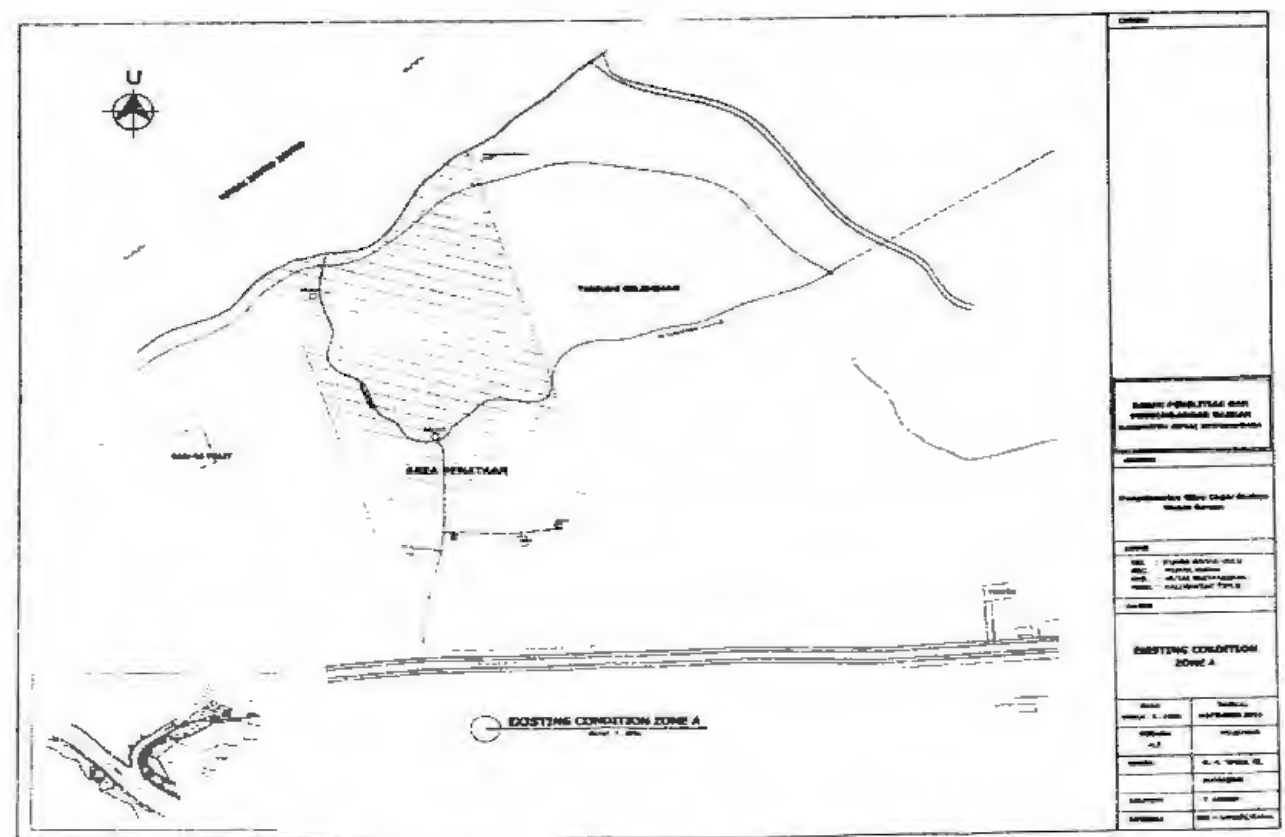

Peta Zone A dan Areal Pengembangannya 


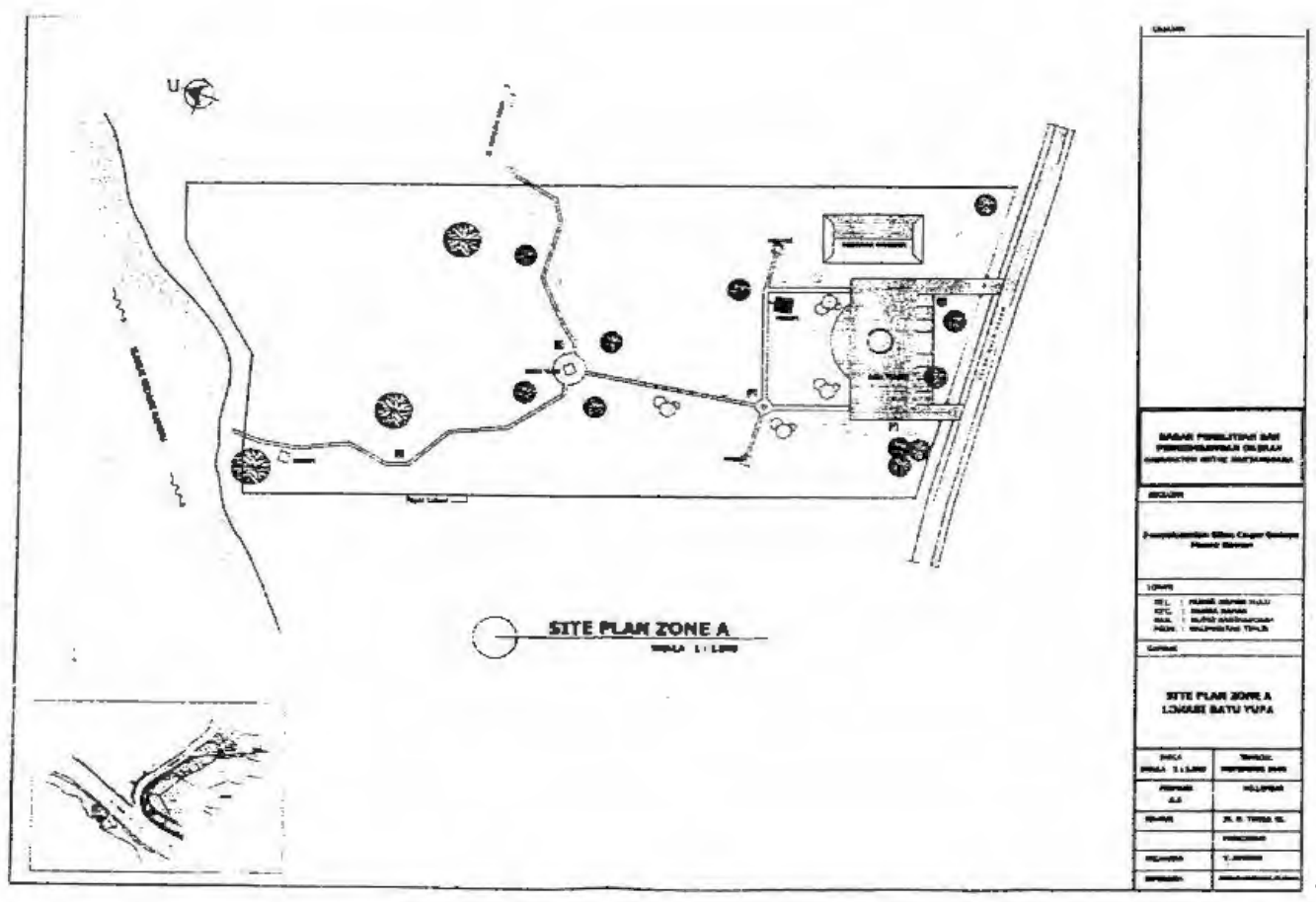

Peta Zone A dan Areal Pengembangannya

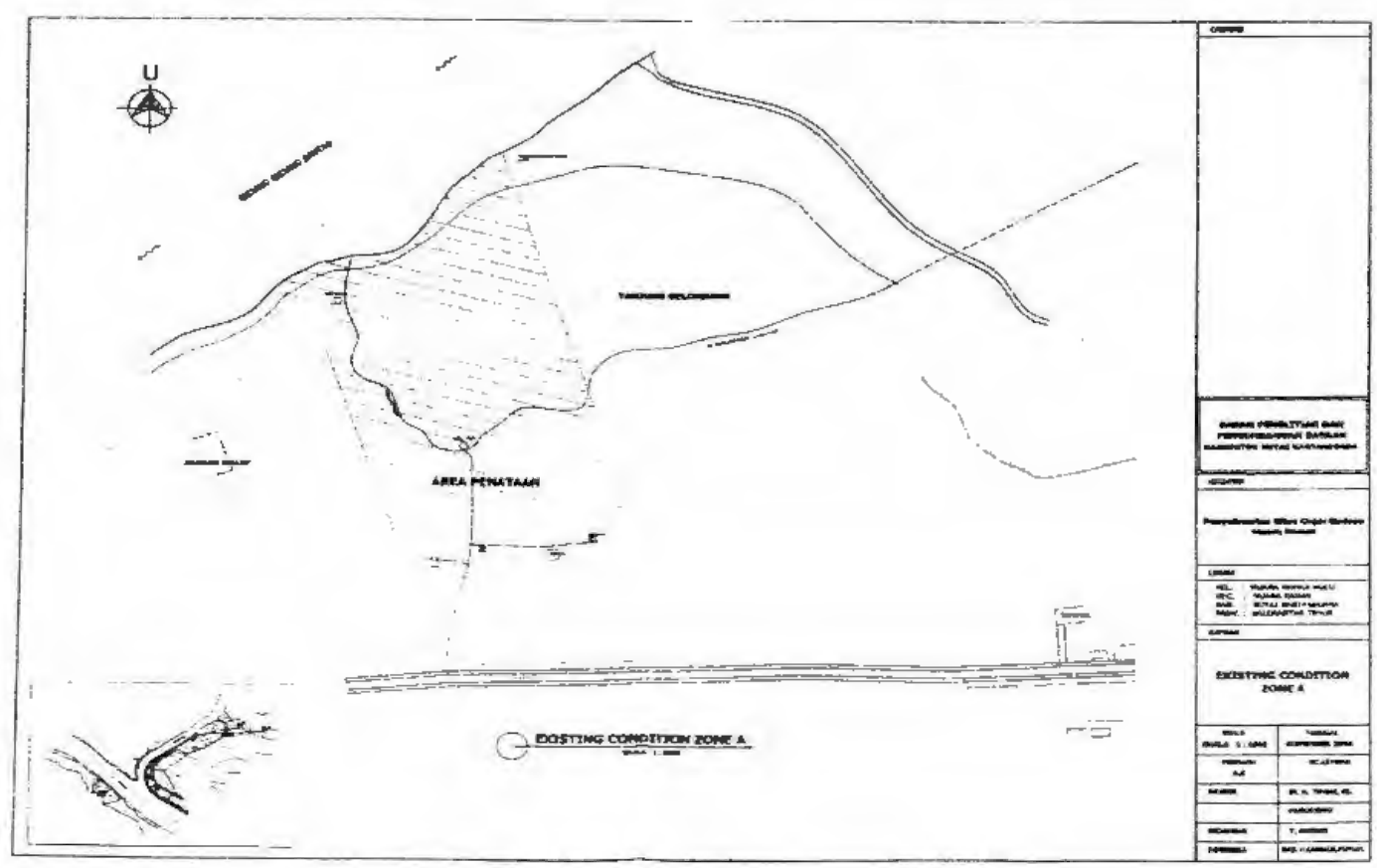

Peta Zone A dan Areal Pengembangannya 


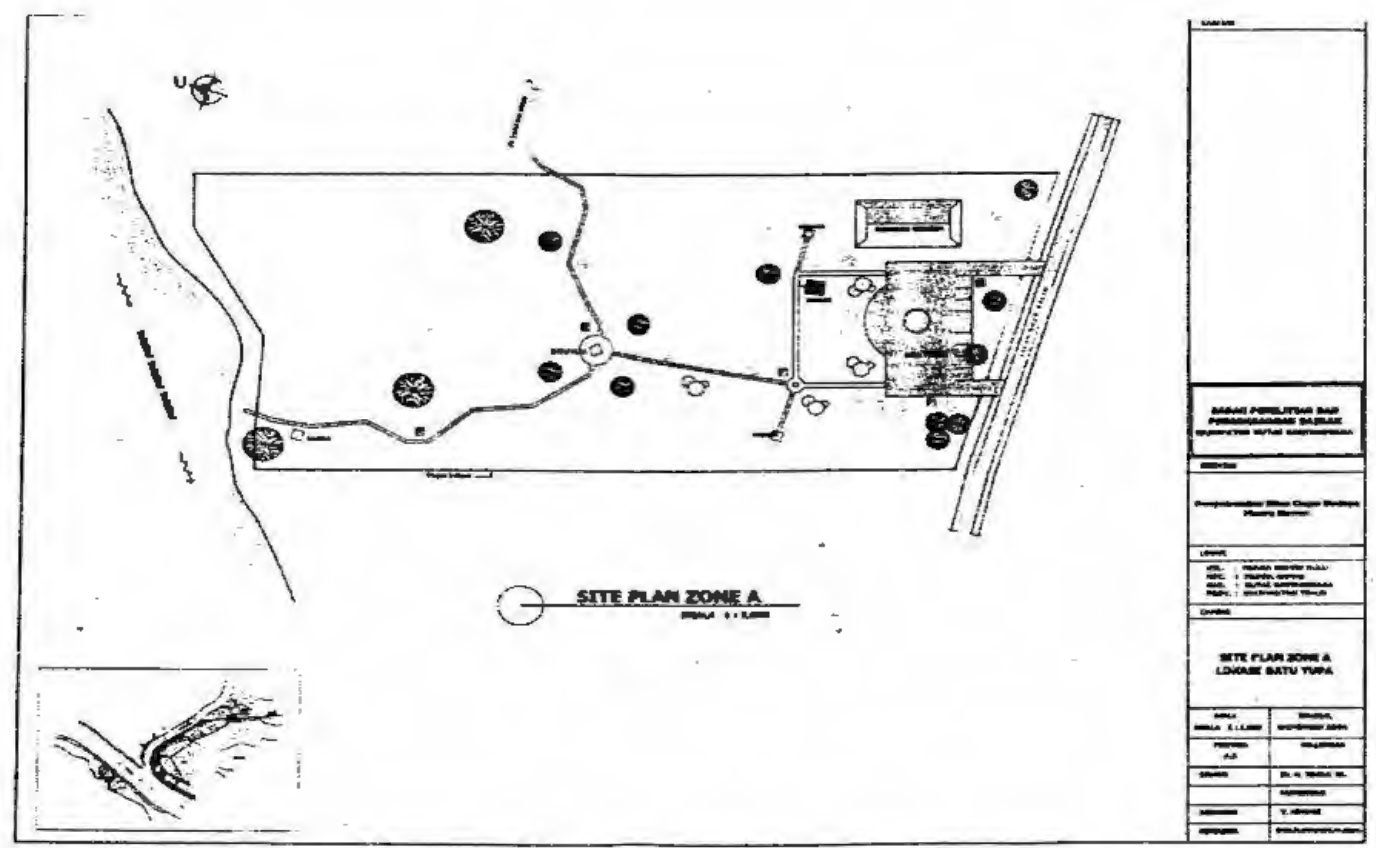

Peta Zone A dan Areal Pengembängañnya

Lampiran Daftar Temuan Lepas Ha sil Survei di Bukit Martapura

\begin{tabular}{|c|c|c|c|c|}
\hline No. & Jenis Temuan & Asal Benda dan Abad & \multicolumn{2}{|c|}{ Bahan dan Jumlah } \\
\hline 1. & Fr. Badan piring & Sukhotai - Abad XV & Stoneware & 2 \\
\hline 2. & Fr. Badan piring & Vietnam - Abad XV/XVI & Porselin & -2 \\
\hline 3. & Fr.Badan tempayan & Vietnam - Abad XVI & Stoneware & -1 \\
\hline 4. & Fr.Tepian piring & Celadon - Abad XVI & Stoneware & -2 \\
\hline 5. & Fr.Badan piring & s.d.a. & s.d.a. & -1 \\
\hline 6. & Fr.Dasar piring & s.d.a" & s.d.a. & -1 \\
\hline 7. & Fr.Tepian piring & Ming Swato Abad XVI & s.d.a. & -2 \\
\hline 8. & Fr.Tepian mangkok & s.d.a. & s.d.a. & \\
\hline 9. & Fr.Badan piring & s.d.a. & s.d.a. & - \\
\hline 10. & Fr.dasar piring & s.d.a. & s.d.a. & - \\
\hline
\end{tabular}




\begin{tabular}{|c|c|c|c|c|}
\hline 11. & s.d.a & s.d.a. & s.d.a. & -1 \\
\hline 12. & Fr.Tepian piring & Ming Вiru/putih - Abad XVI & s.d.a. & -2 \\
\hline 13. & Fr.tepian mangkok & -Abad XVII & Porselin & -1 \\
\hline 14. & Fr.Badan piring & Ming biru/putih- Abad XVI & s.d.a. & -5 \\
\hline 15 . & Fr.Badan mangkok & s.d.a. & s.d.a. & -3 \\
\hline 16. & Fr.dasar piring & s.d.a. & Porselin & -3 \\
\hline 17. & s.d.a. & Ming polos putih & s.d.a. & -1 \\
\hline 18. & Fr.tepian mangkok & Qing - Abad XVIII & s.d.a. & -2 \\
\hline 19. & Fr.badan mangkok & s.d.a. & s.d.a. & -3 \\
\hline 20. & Fr.Badan piring & s.d.a. & s.d.a. & $-\quad 2$ \\
\hline 21 & Fr.badan tempayan & Sawankhalok abad XVI & Stoneware & -4 \\
\hline 22 & s.d.a. & s.d.a. & s.d.a. & -1 \\
\hline 23 & Fr.tepian tempayan & Guandong abad XVII/XVIII & s.d.a. & -1 \\
\hline 24 & Fr.badan tempayan & s.d.a. & s.d.a. & -3 \\
\hline 25 & Fr.badan piring & Vietnam abad XV/XVI & s.d.a. & -2 \\
\hline 26 & Fr.Badan cepuk & Sawankhalok abad XVI & s.d.a. & -1 \\
\hline
\end{tabular}

Daftar Temuan Lepas Hasil Survei di Tanjung Gelombang

\begin{tabular}{|c|l|c|cc|}
\hline No. & \multicolumn{1}{|c|}{ Jenis Temuan } & \multicolumn{2}{|c|}{ Asal Benda dan Abad } & \multicolumn{2}{|c|}{ Bahan dan Jumlah } \\
\hline 1. & Fr.dasar piring & Cimpay Yuan-Abad XIV & Stoneware & -1 \\
2. & Fr.badan piring & Sukhotai - Abad XV & s.d.a - & 1 \\
3. & Fr.badan tempayan & Sawankhalok-Abad XVI & s.d.a.- & 1 \\
4. & Fr.dasar tempayan & s.d.a. & s.d.a.- & 1 \\
5. & Fr.dasar mangkuk & s.d.a. & s.d.a.- & 1 \\
6. & Fr. S.d.a. & s.d.a. & s.d.a.- & 2 \\
7. & Fr.badan mangkuk & s.d.a. & s.d.a.- & 2 \\
8. & Fr.tepian piring & s.d.a. & s.d.a.- & 1 \\
9. & Fr. S.d.a. & Vietnam Abad XV/XVI & s.d.a.- & 1 \\
10. & Fr.dasar piring & s.d.a. & s.d.a.- & 4 \\
\hline
\end{tabular}




\begin{tabular}{|c|c|c|c|c|c|}
\hline 11. & Fr.badan tempayan & & s.d.a. & s.d.a.- & 11 \\
\hline 12. & Fr.dasar piring & Ming Swat & ow-Abad XVI & s.d.a.- & 1 \\
\hline 13. & Fr. S.d.a & Ming putih & -Abad XVI & Porselin - & 2 \\
\hline 14. & Fr.dasar mangkuk & Ming biru- & putih-Abad XVI & s.d.a.- & 1 \\
\hline 15. & Fr.tepian piring & & s.d.a. & s.d.a.- & 1 \\
\hline 16. & Fr.badan piring & & s.d.a. & s.d.a.- & 1 \\
\hline 17. & Fr.tutup cepuk & & s.d.a. & s.d.a.- & 1 \\
\hline 18. & Fr.dasar vas & & s.d.a. & s.d.a.- & 1 \\
\hline 19. & Fr.tepian mangkuk & Qing Abr & d XVII-XVIII & s.d.a.- & 1 \\
\hline 20. & Fr.badan mangkuk & & s.d.a. & s.d.a.- & 1 \\
\hline 21 . & Fr.badan tempayan & Guandong & Abad XVIII & Stoneware - & 1 \\
\hline 22. & Fr. S.d.a. & & s.d.a. & s.d.a.- & 2 \\
\hline 23. & Fr. S.d.a. & & s.d.a. & s.d.a.- & 1 \\
\hline 24. & Fr.tepian mangkuk & & s.d.a. & s.d.a.- & 1 \\
\hline
\end{tabular}

Daftar Temuan Lepas Hasil Survei di Sekitar Makam Ban ua Lawas

\begin{tabular}{|c|l|c|cc|}
\hline No. & \multicolumn{1}{|c|}{ Jenis Temuan } & Asal Benda dan Abad & \multicolumn{2}{|c|}{ Bahan dan Jumlah } \\
\hline 1. & Fr.dasar piring & Vietnam Abad XV-XVI & Stoneware 1 \\
2. & Fr.dasar mangkuk & Sawankhalok Abad XVI & s.d.a. - & 2 \\
3. & Fr.badan piring & s.d.a. & s.d.a. & 3 \\
4. & Fr.badan tempayan & Guandong Abad XVII-XVIII & s.d.a. - & 3 \\
5. & Fr.dasar piring & Swatow Abad XVII & Porselin - & 1 \\
\hline
\end{tabular}




\section{Daftar Temuan Pecahan Gerabah Hasil Survei Permukaan}

\begin{tabular}{|c|c|c|c|c|}
\hline No. & Temuan & Lokasi & Jumlah & Keterangan \\
\hline 1. & Fr.badan periuk & Gn. Martapura & 4 & Berhias garis-2 \\
2. & s.d.a. & s.d.a. & 2 & s.d.a. \\
3. & Fr. tepian & s.d.a. & 2 & - \\
4. & Fr. badan & s.d.a. & 7 & - \\
5. & s.d.a. & s.d.a & 3 & - \\
6. & s.d.a. & s.d.a. & 2 & - \\
7. & Fr. pegangan & Tanjung & 1 & berhias \\
8. & s.d.a. & Gelombang & 1 & s.d.a. \\
9. & Fr. tepian & s.d.a. & 1 & - \\
10. & Fr. badan & s.d.a. & 4 & berhias \\
\hline 11. & s.d.a. & s.d.a. & 1 & \\
\hline
\end{tabular}

\section{Lampiran Daftar Situs dan Posisi Koordinat}

\begin{tabular}{|c|c|c|c|}
\hline No. & Nama Situs & \multicolumn{2}{|c|}{ Koordinat } \\
\hline 1. & Monumen Tugu Perjuangan & S 00935.3 & E 1164305.7 \\
\hline 2. & Kompleks Makam Martadipura & S 00928.3 & E 1164232.6 \\
\hline 3. & Situs Permukiman PLN M.Kaman & S 00854.6 & E 1164328.3 \\
\hline 4. & Situs Candi A Lok. Pak Kotoi & S 00853.7 & E 1164330.4 \\
\hline 5. & Situs Candi B Lok. Pak Kotoi & S 00854.2 & E 1164330.8 \\
\hline 6. & Lesung Baru (Yupa?) & S 00846.6 & E 1164332.8 \\
\hline 7. & Posisi awal Berdirinya Batu Yupa(?) & S 00844.7 & E 1164331.3 \\
\hline 8. & Tiang-tiang Kayu Rumah tua & S 00839.9 & E 1164346.0 \\
\hline 9. & Situs Tanjung Serai & S 00844.5 & E 1164351.2 \\
\hline 10. & Danau Lipan & S 00925.0 & E 1164312.3 \\
\hline
\end{tabular}

